\title{
Correction to: PKU dietary handbook to accompany PKU guidelines
}

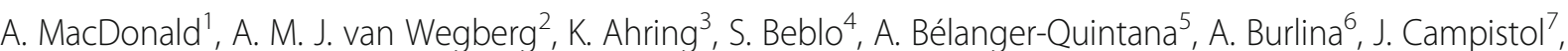 \\ T. Coşkun ${ }^{8}$, F. Feillet ${ }^{9}$, M. Giżewska10 ${ }^{10}$, S. C. Huijbregts' ${ }^{11}$, V. Leuzzi $^{12}$, F. Maillot ${ }^{13}$, A. C. Muntau ${ }^{14}$, J. C. Rocha ${ }^{15}$, \\ C. Romani ${ }^{16}$, F. Trefz ${ }^{17}$ and F. J. van Spronsen ${ }^{2^{*}}$
}

\section{Correction to: Orphanet J Rare Dis 15, 171 (2020) https://doi.org/10.1186/s13023-020-01391-y}

The original article [1] contained an error in the Sport and Nutrition section of the manuscript whereby it was stated that:

\section{'Approximately 20-30 g of protein equivalent from protein substitute should be ingested post exercise.'}

This sentence should instead have stated ' ... $20 \mathrm{~g}$ of protein equivalent from protein substitute ... ' which has since been implemented in the original article.

\section{Author details}

'Dietetic Department, Birmingham Children's Hospital, Birmingham, UK.

${ }^{2}$ Division of Metabolic Diseases, Beatrix Children's Hospital, University Medical Centre Groningen, University of Groningen, Hanzeplein 1, 9700 RB

Groningen, The Netherlands. ${ }^{3}$ Department of PKU, Kennedy Centre, Glostrup, Denmark. ${ }^{4}$ Department of Women and Child Health, Center for Pediatric Research Leipzig, Hospital for Children and Adolescents, University Hospitals, Leipzig, Germany. ${ }^{5}$ Department of Paediatrics, Hospital Ramon y Cajal Madrid, Metabolic Diseases Unit, Madrid, Spain. ${ }^{6}$ Division of Inherited Metabolic Diseases, Department of Paediatrics, University Hospital of Padova, Padova, Italy. ${ }^{7}$ Neuropaediatrics Department, Hospital Sant Joan de Déu, Universitat de Barcelona, Barcelona, Spain. ${ }^{8}$ Hacettepe University Faculty of Medicine, Ankara, Turkey. ${ }^{9}$ Department of Paediatrics, Hôpital d'Enfants Brabois, CHU Nancy, Vandoeuvre les Nancy, France. ${ }^{10}$ Department of Paediatrics, Endocrinology, Diabetology, Metabolic Diseases and Cardiology of the Developmental Age, Pomeranian Medical University, Szczecin, Poland. ${ }^{11}$ Department of Clinical Child and Adolescent Studies-Neurodevelopmental Disorders, Faculty of Social Sciences, Leiden University, Leiden, The Netherlands. ${ }^{12}$ Department of Paediatrics, Child Neurology and Psychiatry,

\footnotetext{
The original article can be found online at https://doi.org/10.1186/s13023020-01391-y.

*Correspondence: f.j.van.spronsen@umcg.nl

${ }^{2}$ Division of Metabolic Diseases, Beatrix Children's Hospital, University Medical Centre Groningen, University of Groningen, Hanzeplein 1, 9700 RB Groningen, The Netherlands
}

Full list of author information is available at the end of the article
Sapienza University of Rome, Via dei Sabelli 108, 00185 Rome, Italy. ${ }^{13} \mathrm{CHRU}$ de Tours, Université François Rabelais, INSERM U1069, Tours, France. ${ }^{14}$ University Children's Hospital, University Medical Centre Hamburg-Eppendorf, 20246 Hamburg, Germany. ${ }^{15}$ Nutrition \& Metabolism, NOVA Medical School, Faculdade de Ciências Médicas, Universidade Nova de Lisboa, Lisbon, Portugal. Centre for Health Technology and Services Research (CINTESIS), Porto, Portugal. ${ }^{16}$ School of Life and Health Sciences, Aston University, Birmingham, UK. ${ }^{17}$ Department of Paediatrics, University of Heidelberg, Heidelberg, Germany.

Published online: 01 September 2020

\section{Reference}

1. MacDonald A, et al. PKU dietary handbook to accompany PKU guidelines. Orphanet J Rare Dis. 2020;15:171 https://doi.org/10.1186/s13023-020-01391y.

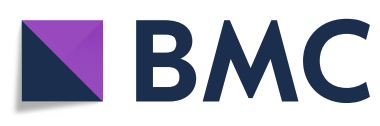

(c) The Author(s). 2020 Open Access This article is licensed under a Creative Commons Attribution 4.0 International License, which permits use, sharing, adaptation, distribution and reproduction in any medium or format, as long as you give appropriate credit to the original author(s) and the source, provide a link to the Creative Commons licence, and indicate if changes were made. The images or other third party material in this article are included in the article's Creative Commons licence, unless indicated otherwise in a credit line to the material. If material is not included in the article's Creative Commons licence and your intended use is not permitted by statutory regulation or exceeds the permitted use, you will need to obtain permission directly from the copyright holder. To view a copy of this licence, visit http://creativecommons.org/licenses/by/4.0/. The Creative Commons Public Domain Dedication waiver (http://creativecommons.org/publicdomain/zero/1.0/) applies to the data made available in this article, unless otherwise stated in a credit line to the data. 